\title{
The Impact of Corporate Social Responsibility on Firm Performance: Evidence from Non- financial Sector in ASEAN-5 Countries 2012- 2016
}

\author{
Weneng Sandewa \\ Faculty of Economics and Business \\ Universitas Indonesia \\ Depok, Indonesia \\ wenengsandewa19@gmail.com
}

\author{
Rahmat Aryo Baskoro \\ Faculty of Economics and Business \\ Universitas Indonesia \\ Depok, Indonesia \\ aryobaskoro.feui@gmail.com
}

\begin{abstract}
The objective of this research is to analyze the impact of corporate social responsibility (CSR) on company performance for non-financial companies in the ASEAN-5Indonesia, Malaysia, Singapore, Thailand, and the Philippines-during the 2012-2016 period. This research uses the fixed effect regression model. The results indicate that CSR has a negative and significant relationship to company performance for non-financial companies in the ASEAN-5. So that, companies with strong CSR are expected to have reduced company performance.
\end{abstract}

Keywords-corporate social responsibility, financial performance, ASEAN - 5, period 2012-2016

\section{INTRODUCTION}

Business development today shows that the purpose of a business or company is not only to achieve maximum profits but also to meet the needs of its stakeholders. H.R. Bowen stated that business people are obligated to pursue policies, make decisions, and implement actions that are in line with society's goals and values [1,2].

Expressed his idea that a company through its daily activities has three different types of responsibilities: economic responsibility, legal responsibility, and social responsibility [1]. The view according to Bowen and Post expressed the concept of corporate social responsibility (CSR) [1].

Stakeholder theory states that companies improve their CSR performance when serving implicit claims from stakeholders because of the positive influence of CSR on the company through a good corporate reputation, increased employee loyalty, and excellent public support [2]. A corporate strategy that leads to high social performance can improve the company's financial performance [3].

In Indonesia, the government and companies are paying attention to CSR [4]. The obligation to conduct CSR programs is fulfilled by all companies via the criteria set by the government. Therefore, that numerous regulations exist for CSR programs in Indonesia is not surprising.

Malaysia is one of the most active countries in generating CSR components in its economic measurements [5]. The
Malaysian government issued a guideline called The Environmental Quality Act, which aims to address issues related to environmental pollution and security and to instruct construction companies to undertake an environmental impact assessment before developing projects. In Indonesia, the Malaysian Institute of Integrity focuses on the issue of CSR [5].

CSR development in Singapore is not very good [6]. A 2008 survey conducted by the Singapore Ministry of Industry and Commerce published in the "CSR Singapore Style" journal showed that $60 \%$ of companies in Singapore are not concerned with CSR, 3\% are concerned about CSR but are not willing to develop CSR programs, and only $27 \%$ are concerned and want to develop CSR programs [6]. Regulations by the Singapore government related to CSR programs include three components: workers' rights, corporate governance, and environmental protection [6].

In Thailand, CSR is a concept for how a business "goes back to society." This concept is about the responsibility of a company to provide to both local communities and society as a whole. In addition, CSR responsibility comes not only in the form of programs but also is a medium used to enable relationships to develop between organizations and society [7]. In Thailand, the development of the CSR concept is very advanced, which is evidenced by the establishment of the Corporate Social Responsibility Institute at the Stock Exchange of Thailand (SET), the New CSR Department at the Royal Foundations, and the Network of NGOs and Business Partnerships for Sustainable Development [7].

The last country is the Philippines. In this country, the Philippine Business for Social Progress has the duty to provide funds for community self-help organizations and address various social issues, such as human resource development through education cost assistance programs [8]. The institute is also concrete proof of the contribution of Philippines' corporations to social development. This institution was established to gather resources from strategic companies that could subsequently be used to support programs that promote self-reliance, sustainable development, and economic growth in the Philippines [8]. 
The ASEAN CSR Network was established with the objective to develop cooperation and the same information about CSR in countries incorporated in the ASEAN [9]. The ASEAN CSR Network is in line with the Blueprint for an ASEAN Socio-Cultural Community (2008-2015). Currently, the general guidelines used by all countries in implementing CSR programs is ISO 26000. This guide has been prepared by various participating parties, including businesses, governments, NGOs, academia, consumers, laborers, and others, from almost 100 countries, including Indonesia and 40 international / regional institutions [9]. The focus of ISO 26000 is on organizational governance, human rights, employment, the environment, fair operations, consumer issues, and community development. This ISO 26000 guide is also used as a standard in the implementation of CSR programs in the ASEAN region $[9,10]$.

Separate attention is paid to CSR assessments of a company. CSRHUB releases the CSR rating of companies that already have CSR programs, not only in the ASEAN region but also in global companies. CSRHUB's results show that ASEAN companies have on average a good CSR rating, with numbers within the 45-65 range.

In the Global Corporate Sustainability Report 2015 by Nielson, people in the ASEAN are willing to pay more for sustainability products or services than any other citizens in the world [9]. Therefore, even if a company budgets a high cost for its CSR program, the significant public awareness of CSR means that the company need not worry about the costs incurred because, through CSR, community loyalty will support its products. In this way, the company's earnings will be maintained and may even increase. This increase will certainly have an effect on the company's performance [9].

Many comparison ratios can be used to analyze a company's performance. Such ratios include the liquidity ratio, solvency ratio, activity ratio, profitability ratio, and investment ratio [11]. The profitability ratio is commonly used to evaluate a company's performance and reflects the company's ability to earn profits by using all available resources through sales activity, cash, capital, number of employees, number of branches, and others [11].

Two types of commonly used comparison indicators are used as profitability ratios, which are return on assets (ROA) and return on equity (ROE). ROA reflects how much money the company can generate from existing company assets. ROE indicates how much money the company can generate from existing investments.

Good corporate financial performance is inseparable from the support of all parties both within and outside the company. Moreover, in the current era, the role of external parties must be noticed by the company. Therefore, the company's performance is associated with CSR. Yang and Baasandorj showed that full-service airline carriers were able to improve their financial performance through established social activities [3]. Rhou, Singal, and Koh found that restaurant companies or restaurants that conduct CSR activities experience increased financial gains [2]. The adoption of strategic and non-strategic CSR has a significant positive and negative impact on corporate financial performance [11].

Implementation of CSR activities in companies incorporated in the ASEAN requires further research into company performance, particularly if the activities are in one of the five major countries - Indonesia, Singapore, Thailand, Malaysia, and the Philippines. To that end, the authors are interested in conducting research entitled, "Analysis the Impact of CSR on Firm Performance: Evidence from NonFinancial Sector in ASEAN-5 Countries Period 2012-2016."

The proposed outputs of this research are as follows.

- Determine the Impact of CSR on Firm Performance: Evidence from Non-Financial Sector in ASEAN-5 Countries Period 2012-2016.

- Determine the Impact of Size on Firm Performance: Evidence from Non-Financial Sector in ASEAN-5 Countries Period 2012-2016.

Determine the Impact of Leverage on Firm Performance: Evidence from Non-Financial Sector in ASEAN-5 Countries Period 2012-2016.

\section{LITERATURE REVIEW AND HYPOTHESIS DEVELOPMENT}

\section{A. Agency Theory}

Agency theory explains the agency relationship between the shareholder as principal and the manager as agent. This relationship occurs when one or more individuals as the principal pay / exploit other individuals or organizations to perform a number of services and delegate decision-making authority to the designated individual or organization, called the agent $[8,11,13]$. Robinson and Pearce stated that the owner's interest might be neglected given the separation between the agent and the owner [11].

\section{B. Stakeholder Theory}

Stakeholder theory includes values, legal compliance, community, and environmental awards, and the business world's commitment to contributing to sustainable development. Freeman stated the assumptions that business activity explicitly and undeniably has value $[8,11,12]$.

\section{Legitimacy Theory}

CSR activity has the purpose of aligning the company's position with the norms and values of society. The expectation is that, through the company's CSR activities, it will gain legitimacy and recognition from the public. Thus, when this legitimacy has been established, the company can easily engage in its activities to achieve maximum performance and profit $[3,8,11,12]$.

\section{Free Cash Flow Theory}

CSR activity has the purpose of aligning the company's position with the norms and values of society. The expectation is that, through the company's CSR activities, it will gain legitimacy and recognition from the public. Thus, when this legitimacy has been established, the company can easily engage in its activities to achieve maximum performance and profit $[3,8,11,12]$.

\section{E. CSR}

Ness (1992) explained that CSR is a strategic decision by a company to fulfill its obligation to society and the environment. CSR is viewed as a continuous and sustained corporate sustainability report that companies can use in their 
long-term strategies. Similarly, as stated by Kotler and Lee (2005) [10], CSR is a voluntary corporate commitment to improving community welfare and is not a business activity required by law or legislation. ISO 26000 introduced seven CSR principles [9], as follows:

- Accountability, which means that companies must be transparent and accountable for any activity in which they engage.

- Transparency; to reduce information asymmetries, misconceptions, and especially information and responsibilities that affect the environment, companies should provide transparency to their stakeholders.

- Ethical behavior has a direct relationship to a company's business strategy. Companies that uphold ethical behavior tend to have a good long-term business strategy. This principle emphasizes that companies not violate ethical behavior that could be harmful in the future.

- $\quad$ Respect the needs of stakeholders, which emphasizes that a company always participate in meeting the needs of its stakeholders given the existence of those who cannot be separated from the success it achieves.

- Respect applicable law means that companies as businesses are required to comply with the applicable laws related to its operational activities.

- Honoring international norms.

- Respecting human rights requires companies to care about human rights and not just the environment. These rights are interest based, right based, and duty based [8].

Furthermore, Divided CSR reporting into three categories [10]: economic performance, environmental performance, and social performance. Economic performance includes sales growth, share value, margin growth, and others. Social performance includes customer satisfaction, employees, capital providers, and the public sector. Environmental performance includes raw materials, energy, water biodiversity, waste river emissions, suppliers and services, implementation, and transport. Social performance is subdivided into four categories: (1) work practices consisting of security and labor safety, education and training, and employment opportunities; (2) human rights consisting of strategy and management, non-discrimination, freedom of association and assembly, labor age, and discipline and security; (3) social consisting of community, corruption, competition, and pricing; and (4) responsibility for products consisting of the health and safety of customers and advertisements concerned with private rights.

\section{F. Financial Performance}

Financial performance is represented by the end result of the accounting activities (accounting cycle) that reflect the financial condition and results of the operations of the company, presented in the form of financial statements [12, 13]. Furthermore, Brigham and Houstan stated that financial performance is on sheets of paper with numbers written on them but also that thinking about real assets based on those figures is important. Here are tables showed the descriptive statistics analysis of the research $[8,13]$.

TABLE I. TABLE OF DESCRIPTIVE STATISTICS ANALYSIS

\begin{tabular}{|l|c|c|c|c|c|c|}
\hline Variable & Obs & Mean & Median & Max & Min & $\begin{array}{c}\text { Std. } \\
\text { Deviation }\end{array}$ \\
\hline ROA & 539 & 8.947161 & 6.390000 & 75.32000 & -8.580000 & 9.464911 \\
\hline CSR & 540 & 52.45104 & 55.80000 & 94.00000 & 0.619444 & 22.32255 \\
\hline LEV & 540 & 88.97046 & 64.74000 & 1580.460 & 0.000000 & 114.8004 \\
\hline SIZE & 540 & 18.46470 & 17.59780 & 26.27574 & 12.69794 & 22.32255 \\
\hline
\end{tabular}

TABLE II. TABLE OF RESEARCH DATA

\begin{tabular}{|l|l|l|}
\hline \multicolumn{1}{|c|}{ Variable } & Notation & Data Resource \\
\hline Dependent Variable & ROA & Data Stream Thomson Reuter \\
\hline Firm Performance & RA \\
\hline Independent Variable & CSR & Data Stream Thomson Reuter \\
\hline CSR & \multicolumn{2}{|l}{} \\
\hline Control Variable & LEV & Data Stream Thomson Reuter \\
\hline Leverage & SIZE & Data Stream Thomson Reuter \\
\hline SIZE &
\end{tabular}

Some of the indicators used to evaluate the company's financial performance are ROA and ROE.

- ROA is a ratio or comparison that indicates the extent of a business' return on all. Furthermore revealed that the meaning of ROA is a description of the ability of assets owned by the company to generate profits.

- ROE is a company's measure of earning profits available to shareholders. This measurement views the company's ability to generate profits and reflects the ROE of the firm's owners. Describe ROE as the ratio that drives the return of the business over all of its capital.

\section{METHOD}

\section{A. Research Design}

This research was conducted to understand the impact of CSR on firm performance in the ASEAN-5, including Indonesia, Singapore, Malaysia, Thailand, and the Philippines. This research consists of three variables: the dependent variable, the control variables, and the independent variable. The dependent variable is company performance. The independent variable is CSR, and the control variables are company size and leverage. This research is quantitative in nature.

\section{B. Sampling Method}

Sample and data collection is done using Thomson Reuters Datastream at the Learning Resources Center of Faculty of Economics and Business, Universitas Indonesia. Another source used in this study is CSRHUB, an institution that focuses on rating companies listed on the stock exchanges of each state in terms of the quality of their CSR. 


\section{Data Type}

The data used in this study is categorized as panel data, which is a combination of time series data and crosssectional data. The following data criteria are used.

- The company is a non-financial company operating in one of the five major ASEAN countries, including Indonesia, Malaysia, Thailand, Singapore, and the Philippines.

- The companies are listed on stock exchanges in each of the countries in which they operate.

- The companies have been engaged in CSR activities.

- The companies have data for use in the research.

TABLE III. The TABLE OF MUlticolineARITY TeST

\begin{tabular}{|l|l|l|l|}
\hline & CSR & \multicolumn{1}{|c|}{ SIZE } & \multicolumn{1}{c|}{ LEV } \\
\hline CSR & 1.000000 & & \\
\hline SIZE & 0.109532 & 1.000000 & -0.051560 \\
\hline LEV & 0.130624 & -0.051560 & 1.000000 \\
\hline
\end{tabular}

TABLE IV. THE TABLE OF HETEROSCEDASTICITY TEST

\begin{tabular}{|l|l|l|}
\hline \multicolumn{1}{|c|}{ Variable } & \multicolumn{1}{c|}{ Prob. } & \multicolumn{1}{c|}{ Conclusion } \\
\hline CSR & 0.1154 & There is heteroskedasticity \\
\hline SIZE & 0.0335 & There is no heteroskedasticity \\
\hline LEV & 0.6433 & There is heteroskedasticity \\
\hline
\end{tabular}

\section{Data Processing Method}

Data processing was done by first collecting data from Thomson Reuters Datastream and then processing them using Microsoft Office Excel and Eviews 9.

\section{E. Research Sample}

- Sample Time; the research period was conducted for the last five years, from 2012 to 2016, with the intention to obtain a broader data picture and more relevant data results.

- Company Sample; the companies used in this research are non-financial companies that have complete data availability for all of the variables used. The company must be listed on the stock exchanges of one of the ASEAN-5 countries (Indonesia, Malaysia, Thailand, Singapore, and the Philippines).

\section{F. Research Model}

ROAit $=\beta 0+\beta 1 \mathrm{CSR}$ it $+\beta 2 \mathrm{SIZE}$ it $+1+\beta 3 \mathrm{LEV}$ it + $1+\varepsilon$ it

where ROA represents corporate performance; CSR represents corporate social responsibility; SIZE represents corporate size; and LEV represents corporate leverage.

\section{RESULT AND DiSCUSSION}

\section{A. Descriptive Statistics Analysis}

Descriptive analysis is conducted with the aim to understand the characteristics of each sample as a whole and to observe the general description of the variable. According to Ghazali, descriptive statistics are the results of tests that indicate the picture of the data based on the mean (average), maximum, minimum, and standard deviation [13].

- ROA; the result of the combined descriptive test during 2012-2016 shows a mean of 8.947161, a median of 6.390000 ; and a standard deviation of 9.464911. The maximum is 75.32000 , and the minimum is -8.580000 .

- CSR; the result of the combined descriptive test during 2012-2016 shows a mean of 52.45104, a median of 55.80000 , and deviation standard of 22.32255. The maximum is 94.00000 , and the minimum is 0.619444 .

- Total Assets; the result of the combined descriptive test during 2012-2016 shows a mean of 18.46470, a median of 17.59780, and a standard deviation of 3.133105. The maximum is 26.27574 , and the minimum is 12.69794 .

- Leverage; the result of the combined descriptive test during 2012-2016 shows a mean of 88.97046, a median of 64.74000 , and a standard deviation of 114,8004 . The maximum is 1580.460 , and the minimum is 0.000000 .

\section{B. Multicollinearity Test}

Based on the test results, all variables have a correlation coefficient of less than 0.8 . That is, none of the variables violate the rules of multicollinearity. Therefore, the conclusion can be reached that there is no relationship or correlation among the variables.

\section{Heteroskedasticity Test}

Gujarati (2004) [13] stated that the generalized least square method could be used to overcome all problems in a regression model and can turn estimates into an estimate that meets the best linear unbiased estimator assumption.

\section{Autocorrelation Test}

Based on the test results, $\mathrm{dU}$ is 1.86727 , dL is $1.85267,4-$ $\mathrm{dU}$ is $2.13273,4-\mathrm{dL}$ is 2.14733 , and the Durbin-Watson value is 1.777685 . From these values, we obtain the result $\mathrm{dU}<$ DW Stat $<$ (4-dU), allowing for the conclusion that no autocorrelation exists in the research model.

TABLE V. Autocorrelation Test

\begin{tabular}{|l|l|}
\hline \multicolumn{1}{|c|}{ Information } & \multicolumn{1}{c|}{ Result } \\
\hline $\mathrm{N}$ & 539 \\
\hline $\mathrm{K}$ & 3 \\
\hline $\mathrm{dL}$ & 1.85267 \\
\hline $\mathrm{dU}$ & 1.86727 \\
\hline $4-\mathrm{dU}$ & 2.13273 \\
\hline $4-\mathrm{dL}$ & 2.14733 \\
\hline DW Stat & 1.777685 \\
\hline Result & $\mathrm{dU}<\mathrm{DW}$ Stat $<$ (4-dU) \\
\hline Conclusion & There is no autocorrelation. \\
\hline
\end{tabular}

TABLE VI. ThE TABLE OF RESUlts

\begin{tabular}{|l|l|l|}
\hline Adjusted R-Square & & 0.837898 \\
\hline \multicolumn{1}{|c|}{ Variable } & \multicolumn{1}{|c|}{ Coefficient } & Prob. \\
\hline C & 86.88129 & $0.0000^{* * *}$ \\
\hline CSR & -0.080240 & $0.0000^{* * *}$ \\
\hline
\end{tabular}


Table VI indicates that all variables are significant, which is observed from the probabilities lower than 5\%. The coefficients for each variable are constant 86.88129, 0.080240 for CSR, -3.944125 for total assets, and -0.010207 for leverage.

The research model is as follows:

$$
\begin{gathered}
\text { ROAit }=\beta 0+\beta 1 \text { CSR it }+\beta 2 \text { SIZE it }+1+\beta 3 \text { LEV it }+1+ \\
\text { } \begin{array}{c}
\text { ROAit } \\
=86.88129-0.080240 \text { CSRit }+1-3.944125 \text { SIZEit } \\
+1-0.010207 \text { LEVit }+1+\varepsilon \text { it }
\end{array}
\end{gathered}
$$

All independent and control variables (CSR, Leverage, and Size) have a significant and negative influence on company performance.

\section{F. Impact of CSR on Company Performance}

The coefficient of the CSR variable to company performance is -0.080240 (negatively related), which indicates that if the CSR score increases by 1 , the company's performance decrease by 0.080240 . This effect is attributable to the characteristics of consumers in the ASEAN. For example, consumers are not very aware of CSR - they do not pay attention to whether the company producing the product to be consumed is engaged in CSR. When the consumer feels that a product is worth buying, he or she buys it. Therefore, this sentiment affects the income of the company. As a result, companies' CSR programs cost a lot on the one hand, yet are associated with no significant revenue on the other hand.

\section{G. Impact of Leverage on Company Performance}

The coefficient of the Leverage variable to the firm's performance is -0.010207 (negatively related), which indicates that if Leverage increases one time, company performance decreases by 0.010207 . These results are in line with the results of Seo and Kim, who stated that leverage has a negative and significant influence on the company's performance, which is caused by a too high debt level that results in a high interest burden. This interest burden affects both operational and non-operational costs and, thus, disrupts the company's operational performance $[14,15]$.

\section{H. Impact of Size on Company Performance}

The coefficient of the size variable on firm performance is -3.944125 (negatively related), which indicates that a one-time increase in total assets reduces the company's performance by 3.944125 . These results are in line with Seo and Kim, who stated that a larger company has greater difficulty managing its operations and, thus, its performance declines $[14,15]$. This decline occurs possibly because of greater competition among companies with significant assets than with companies with small assets. Moreover, in the current ASEAN countries, the growth of start-up companies is higher, and they display good performance. As a result, companies with large total assets will be faced with significant competition that will degrade their performance. This decline in performance may also be caused by the company's failure to optimize its assets

\section{CONCLUSION AND IMPLICATION}

Based on the empirical test results, the conclusion can be reached that CSR, Size, and Leverage have negative and significant relationships with the performance of nonfinancial companies in the ASEAN-5 during 2012-2016.

\section{RESEARCH LIMITATIONS}

This research has several limitations, as follows.

- This research is limited to only five countries: Indonesia, Malaysia, Singapore, Thailand, and the Philippines.

- Some companies did not have 2016 CSR data, which need to be retrieved from other sources. Therefore, data from these different sources may not describe a company's actual condition.

The variables are limited, with only one dependent variable (ROA), one independent variable (CSR), and two control variables (Leverage and Size).

\section{REFERENCES}

[1] Anthony, R.N. dan V. Govindarajin. 1995. Management Control System. Mc Gra-Hill. New York. Terjemahan K. Tjakrawala. 2003. Sistem Pengendalian Manajemen. Salemba Empat. Jakarta.

[2] Rhou, Y., Singal, M., \& Koh, Y. (2016). CSR and financial performance: The role of CSR awareness in the restaurant industry. International Journal of Hospitality Management, 57, 30-39.

[3] Yang, A. S., \& Baasandorj, S. (2017). Exploring CSR and financial performance of full-service and low-cost air carriers. Finance Research Letters, 23, 291-299.

[4] Pedoman KADIN Tentang Tanggung-Jawab Sosial Perusahaan (CSR) Untuk Mendukung Pembangunan Berkelanjutan, 2005, Jakarta.

[5] Nasir, N. E. M., Halim, N. A. A., Sallem, N. R. M., Jasni, N. S., \& Aziz, N. F. (2015). Corporate Social Responsibility: An Overview from Malaysia. Journal of Applied Environmental and Biological Sciences, 4(10S), 82-87.

[6] Thomas, T. (2009). CSR Singapore Style. Singapore Management University.

[7] Onozawa, N. (2013). A Study of CSR in Thailand (I): Awareness and Practice. Tsukuba Gakuin University.

[8] Lee, S., Seo, K., \& Sharma, A. (2013). Corporate social responsibility and firmperformance in the airline industry: the moderating role of oil prices. Tourism Management, 38, 20-30.

[9] Global Reporting Initiative, G4: Pedoman Pelaporan Berkelanjutan: Prinsip-prinsip Pelaporan dan Pengungkapan Standar.

[10] Solihin, I. (2009). Corporate Social Responsibility: From Charity to Sustainability. Salemba Empat. Jakarta.

[11] Sayekti, Y. (2015). Strategic Corporate Social Responsibility (CSR), Company Financial Performance, and Earning Response Coefficient: Empirical Evidence On Indonesia Listed Company. Social and Behavioral Sciences, 211, 411-420.

[12] McGuire, J. B., Sundgren, A., \& Schneeweis, T. (1988). Corporate social responsibilityand firm financial performance. Academy of management Journal, 31(4), 854-872.

[13] Subramayan, K. R. (2014). Financial statement analysis, Eleventh Edition. McGraw-Hill Education, 2 Penn Plaza, New York.

[14] Lee, S., Seo, K., Sharma, A., 2013a. Corporate social responsibility and firmperformance in the airline industry: the moderating role of oil prices. Tour.Manage. 38, 20-30.

[15] Kim, H.R., Lee, M., Lee, H.T., Kim, N.M., 2010. Corporate social responsibility andemployee company identification. J. Bus. Ethics 95 (4), 557-569. 